\title{
Crop Productivity and Soil Properties under Agroforestry System in Kosi Watershed of Kumaun Himalaya
}

\author{
Manmohan Singh Kanwal, Anil Kumar Yadava and S.C.R. Vishvakarma' \\ Department of Forestry and Environmental Science, Soban Singh Jeena University, Almora-263 601, India \\ 'G.B. Pant 'National Institute of Himalayan Environment' (NIHE), Kosi-Katarmal, Almora-263 643, India \\ "E-mail: kanwal.manmohan3@gmail.com
}

\begin{abstract}
In the hilly region of Kumaun Himalaya agroforestry system is an important source of food, fodder, fuel, fibre, livelihood security, biological diversity and soil conservation. Local inhabitants are primarily dependent on agriculture along with trees maintained on margin of terraces and bunds of crop fields. This study focused on (i) productivity of paddy and wheat crops under agroforestry and sole agriculture, (ii) comparison of soil properties of different land-use sites of Kantli, Dhaniyakot and Sauraal villages situated along different altitudinal gradient in Kosi watershed. Crop yield and harvest index were recorded better under sole agriculture compared to agroforestry system. Overall, 17.8 to $32.6 \%$ higher grain yield of paddy and 13.76 to $24.76 \%$ higher grain yield of wheat crops were recorded under sole agriculture system. Soil properties were better under vegetation compared to control site. Increases in soil organic carbon and better water holding capacity under top soil $(0-15 \mathrm{~cm})$ were noted under agroforestry and forest soil.
\end{abstract}

Keywords: Agroforestry, Kosi watershed, Crop productivity, Soil properties, Kumaun Himalaya

Uttarakhand, with $53,483 \mathrm{~km}^{2}$ area, shares about $9.62 \%$ of total geographical area of Indian Himalayan Region and $1.56 \%$ of India. About $86 \%$ land of the state is mountainous and only $14 \%$ land of total reported area is available for agricultural activities of which $\sim 55 \%$ is under rainfed with cropping intensity of 161 per cent. About 7.81 lakhs ha land area is under agriculture of which 4.43 lakhs $(56.8 \%$ of total agriculture) is under hilly regions and remaining 3.37 lakhs ha is in tarai regions of the state. Average landholding of farmers of hilly region and tarai region of the state is 0.68 ha and 1.77 ha per farmer, respectively. With this smaller land hold, the state needs extra effort to feed population in coming year both for human and cattle populations. Due to increasing demands of food, fodder, fuel, timber and environmental security, Indian agriculture is facing lots of challenges such as: inclusive growth and sustainable livelihoods, agricultural growth, food security, energy security and environmental security in climate change regime. Like other parts of Himalayas, agriculture is the prime occupation of the majority of people in the Uttarakhand Himalayas (Pandey and Singh 1984) and about $70 \%$ of the population still dependent of agriculture and associated activities. Here local people have evolved agriculture with association of natural forests to meet their food, fodder and fuel wood requirement from this system. Farmers are more dependent for organic matter to support soil fertility of farms on forest resources. Here traditional cereal cultivation is done along with indigenous trees on terraced hill slopes.
Traditional AF plays a significant role in livelihood support to farmers of Kumaun Himalaya. Currently, agriculture in the Kumaun Himalaya is rainfed, less productive and subsistence. Agricultural land is fragmented with terraced slopes constituting a fragile ecosystem leading to difficulty in agricultural operations and even not sufficient to meet out the annual demand of food grain of the household. Here agroforestry practices; particularly composition and use pattern of plants seems diverse under different agro-climatic zones. AF system does not meet only some of the primary necessity of the local people but also reduce soil erosion (Guevara-Escobar et al. 2002, Bhatt et al. 2016), improve soil structure and nutrients (Schroth and Sinclair 2003, Jose 2009) through addition of litter fall. It provide sustainable land management by arresting soil degradation and productivity loss due to excessive use and reduces risk of crop failure under uncertain weather and erosion hazards (Saroj and Arora 1994, Rao 2002). At the same time, it improves sites (Maikhuri and Semwal 1997), improve microclimate (Tanga et al 2014, Singh et al 2016), such as lowering of soil surface temperature and reduction of evaporation of soil moisture through a combination of mulching and shading. Moreover, it reduces pressure from forests (liyama et al 2014, Verma et al 2017), conserve biodiversity (Harvey et al 2006, Jose 2009) and sequestrates carbon (Montagnini and Nair 2004, Nair et al 2009, Chauhan et al 2019). 
Studies on agricultural productivity under AF system indicate higher productivity can be achieved under agroforestry system (Fagerholm et al 2016, Waldron et al 2017, Lehmann et al 2020) while in other studies reduced yield under agroforestry was recorded than the sole cropping system (Puri and Bangarwa 1992, Dufour et al 2013, Chauhan et al 2015). However, few studies also recommended higher production under AF system can be achieved by selection of appropriate tree-crop combination (Tadesse et al 2021) and proper management (Semwal et al. 2002 , Broadhead et al 2003). Such practices and knowledge on spatial arrangement, temporal sequence, tree crop combination is limited and scattered in Kumaun Himalaya. In view of this, present study was conducted to understand the productive potential of hill agroforestry system and its impact on soil properties.

\section{MATERIAL AND METHODS}

Srivastava (2006) suggested that central Himalayan region can be divided into four markedly different agro-climatic zones along the elevation gradient i.e., lower altitude, $<800 \mathrm{~m}$, middle altitude between 800 to $1500 \mathrm{~m}$, higher altitude between 1500 to $2000 \mathrm{~m}$ and very high altitude $>2000 \mathrm{~m}$ based on the different farming practices along the elevation zones. Thus, three study villages namely Kantli $(1750 \mathrm{~m})$, Dhaniyakot $(1064 \mathrm{~m})$ and Sauraal $(839 \mathrm{~m})$ were selected for the present study along the altitudinal gradients of Kosi watershed. They represent upper, middle and lower parts of Kosi watershed situated in Uttarakhand state. All the villages have terraced rainfed agriculture in hill slopes. Very smaller part of agricultural land was under irrigation condition. Climatic conditions of the watershed fall under temperate to subtropical zone following the classification of Köppen (1900). The watershed has three prominent seasons; summer (AprilJune), rainy (July-Sept) and winter (Nov-Feb). During the study period, annual air temperature ranged from a maximum of $32.1^{\circ} \mathrm{C}$ (June) to minimum $-0.8^{\circ} \mathrm{C}$ (January) and the mean annual temperature was approximately $18^{\circ} \mathrm{C}$. Rainfall varies from $3 \mathrm{~mm}$ (Nov.) to $287 \mathrm{~mm}$ (Aug.) across the year.

Agricultural productivity: Assessment of agricultural crops productivity under agroforestry systems and sole agriculture was estimated by taking samples of paddy (Oryza sativa) and wheat (Triticum aestivum) crops for two consecutive years from the farmer's fields. A net plot of $1.0 \mathrm{~m} \times 1.0 \mathrm{~m}$ was harvested from agroforestry system as well as sole agriculture system. This sample harvest was done in 5 replicates. Harvested crop was separated into grains and straw. It was dried for 5-6 days and the produce was weighed to obtain the net yield of crops. Average crop yield data were presented in $\mathrm{kg} \mathrm{ha}^{-1}$.

Harvest index: The harvest index is used to denote the fraction of economically useful products of a plant in relation to its productivity. It was obtained by dividing economic yield (grain yield) by biological yield and expressed in percent as follows:

$$
\text { Harvest index }=\frac{\text { Economic yield }}{\text { Biological yield }} \times 100
$$

Soil analysis: Soil samples were collected in $Z$ shape using augur from 3 layers $(0-15 \mathrm{~cm}, 15-30 \mathrm{~cm}$ and $30-45 \mathrm{~cm})$ up to a depth of $45 \mathrm{~cm}$ from agroforestry systems, forests and control sites. Uncultivated cropland without any amendment of organic manure or inorganic manure was treated as control. Three replicates samples were collected from these sites in each study village. Samples from each individual plot were thoroughly mixed to make it composite, air dried and passed through a $2 \mathrm{~mm}$ sieve before chemical analysis. The average

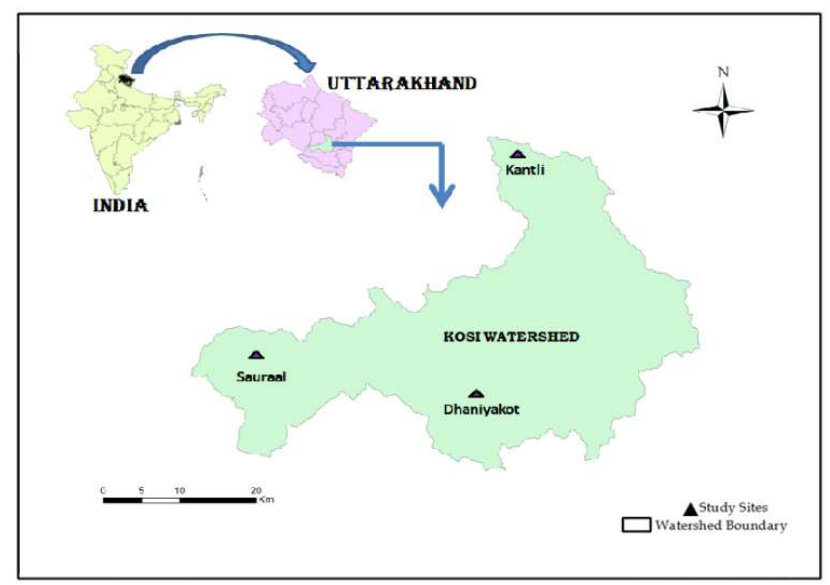

Fig. 1. Location of study sites in Kosi watershed

Table 1. Altitude, agro-climatic condition, area and population of study sites of the Kosi watershed

\begin{tabular}{|c|c|c|c|c|c|c|}
\hline Village & Altitude $(\mathrm{m})$ & Agro-climate & Coordinate & Total area (ha) & $\begin{array}{l}\text { Nos. of total } \\
\text { household }\end{array}$ & $\begin{array}{c}\text { Population } \\
\text { (Residing person) }\end{array}$ \\
\hline Kantli & 1750 & High hills & $\begin{array}{l}\text { N29 } 50^{\prime} 55.06^{\prime \prime} \\
\text { E79 } 33^{\prime} 57.14 "\end{array}$ & 114.57 & 117 & 321 \\
\hline Dhaniyakot & 1064 & Mid hills & $\begin{array}{l}\text { N29 } 29^{\circ} 31.48^{\prime \prime} \\
\text { E79 } 26^{\prime} 56.61^{\prime \prime}\end{array}$ & 128.31 & 212 & 797 \\
\hline Sauraal & 839 & Low hills & $\begin{array}{l}\text { N29 } 32^{\prime} 36.84^{\prime \prime} \\
\text { E79 }^{\circ} 13^{\prime} 31.29^{\prime \prime}\end{array}$ & 260.2 & 100 & 331 \\
\hline
\end{tabular}


values from all the depth were treated as final value. Soil $\mathrm{pH}$, soil moisture content, water holding capacity and organic carbon were analysed using standard methods. Thus soil pH was measured in slurry of soil and deionized water in the ratio of 1:5. All the samples were stirred for 30 minutes and then allowed to stand for approximately 15 minutes before $\mathrm{pH}$ was measured using pre-calibrated digital $\mathrm{pH}$ meter (Jackson 1958). Soil moisture was measured using following ASTM D 2216 method by heating the $10 \mathrm{~g}$ air dried samples at $105^{\circ} \mathrm{C}$ for 24 hours. Water holding capacity was measured using Hilgard cup method (Cassel and Neilson 1986) and organic carbon was estimated using Walkley and Black (1934) method.

\section{RESULTS AND DISCUSSION}

Economic yield: Highest paddy production was recorded at Dhaniyakot followed by Kantli and Sauraal. At Dhaniyakot and Kantli sites paddy yield was relatively higher during IInd year as compared to Ist year under both land-use type. However, decrease trend of grain yield was recorded during IInd year at Sauraal site under agroforestry and sole agriculture. Yield under sole agriculture was higher at all the three study sites and during both the cropping years (Table 2). Total grain yield was 17.8 to $32.6 \%$ higher during Ist year and 18.1 to $29.3 \%$ higher during IInd year under sole agriculture system was recorded in comparison to agroforestry system.

Wheat crop showed nearly similar grain yield pattern like paddy during both years (Table 3). Among all sites, highest wheat production was recorded at Dhaniyakot followed by
Kantli and Sauraal under both the land-use systems. Per hectare wheat yield was higher under sole agriculture as compared to AF system at all the three study sites and during both the cropping years. Under sole agriculture, grain yield was recorded $24.8 \%, 23.9 \%$ and $22.8 \%$ higher than the agroforestry system during Ist year, while 28.8, 21 and $32 \%$ higher under sole agriculture system respectively at Kantli, Dhaniyakot and Sauraal, respectively during second year. Under both land-use systems, increase in grain yield was observed during IInd year except AF system of Sauraal village. Lesser grain yield ( $4 \%$ less) was recorded at Sauraal village under agroforestry during II year. Overall, Maximum grain yield was recorded at Dhaniyakot under both the landuse type among all the study villages. Similar trend was observed in straw yield as well.

Wheat straw also showed lower yield during Ist year as compared to IInd year. Per hectare straw yield was higher under sole agriculture than the AF system under all the three study villages. It was $19.85 \%$ to $24.76 \%$ higher during Ist year and $13.76 \%$ to $22.97 \%$ higher during IInd year under sole agriculture. Overall wheat straw yield was highest at Dhaniyakot followed by Kantli and lowest at Sauraal under both the land-use types.

Biological yield: Biological yield, a sum of straw and grain yield, follows the nearly similar pattern like straw and grain yields of paddy on per hectare basis both under agroforestry and agriculture systems (Table 2). The biological yield was recorded higher during IInd cropping year under both the land-use types as compared to the biological yield of Ist year. Biological yield of paddy under sole agriculture was higher

Table 2. Grains, straw and biological yield of paddy crop under AF system and sole agriculture system in Kosi watershed

\begin{tabular}{|c|c|c|c|c|}
\hline \multirow[t]{2}{*}{ Land use system/Study sites } & & \multicolumn{3}{|c|}{ Paddy yield (kg ha-1) } \\
\hline & & Grain & Straw & Biological \\
\hline \multicolumn{5}{|l|}{ Agroforestry System } \\
\hline \multirow[t]{2}{*}{ Kantli (1750 m amsl) } & $I^{\text {st }}$ Year & $1189 \pm 27$ & $1820 \pm 135.5$ & $3009 \pm 154$ \\
\hline & $\mathrm{II}^{\text {nd }}$ Year & $1245 \pm 29$ & $2103 \pm 148$ & $3348 \pm 174.5$ \\
\hline \multirow[t]{2}{*}{ Dhaniyakot (1064 m amsl) } & $\mathrm{I}^{\mathrm{st}}$ Year & $1396 \pm 34$ & $2130 \pm 75$ & $3526 \pm 112$ \\
\hline & $\mathrm{II}^{\text {nd }}$ Year & $1473 \pm 42$ & $2285 \pm 79.5$ & $3758 \pm 121.5$ \\
\hline \multirow[t]{2}{*}{ Sauraal (839 m amsl) } & $\mathrm{I}^{\mathrm{st}}$ Year & $967 \pm 5$ & $1580 \pm 19.5$ & $2547 \pm 14.5$ \\
\hline & $\mathrm{II}^{\text {nd }}$ Year & $958 \pm 4$ & $1622 \pm 23$ & $2580 \pm 19$ \\
\hline \multicolumn{5}{|l|}{ Sole Agriculture } \\
\hline \multirow[t]{2}{*}{ Kantli (1750 m amsl) } & $I^{\text {st }}$ Year & $1430 \pm 86$ & $2120 \pm 148$ & $3550 \pm 238$ \\
\hline & $I^{\text {nd }}$ Year & $1610 \pm 95.5$ & $2431 \pm 161.5$ & $4041 \pm 252.5$ \\
\hline \multirow[t]{2}{*}{ Dhaniyakot (1064 m amsl) } & $I^{\text {st }}$ Year & $1645 \pm 45$ & $2418 \pm 89.5$ & $4063 \pm 135.5$ \\
\hline & $I^{\text {nd }}$ Year & $1740 \pm 49.5$ & $2607 \pm 99$ & $4347 \pm 149$ \\
\hline \multirow[t]{2}{*}{ Sauraal (839 m amsl) } & $I^{\text {st }}$ Year & $1282 \pm 23$ & $1821 \pm 29$ & $3103 \pm 8.5$ \\
\hline & ${ }^{\text {Ind }}$ Year & $1239 \pm 20.5$ & $1883 \pm 33.5$ & $3122 \pm 12.5$ \\
\hline
\end{tabular}


than biological yield of AF system at all the study sites and during both the cropping years. During Ist cropping year, biological yields was about $18,15.2$ and $21.8 \%$ higher under sole agriculture while IInd cropping year, biological yields were nearly 20.7, 15.7 and $21.0 \%$ higher under sole agriculture than AF systems, respectively at Kantli, Dhaniyakot and Sauraal, respectively. In addition, the highest biological yield was recorded at Dhaniyakot followed by Kantli and minimum at Sauraal during both the cropping year.

Biological yield of wheat crop also showed nearly similar pattern like paddy crop at all the three study villages and under both the land-use types (Table 3). Higher biological yields were recorded under sole agriculture as compared to AF systems. It was nearly 21.9, 22.2 and $23.9 \%$ higher under sole agriculture during Ist cropping year and 25.36, 16.74 and $23.71 \%$ higher than the agroforestry systems, respectively at Kantli, Dhaniyakot and Sauraal during the IInd cropping year. The productivity of biological yield of wheat was highest at Dhaniyakot followed by Kantli during both the cropping year. It was lowest at Sauraal under both the land-use system during both cropping year.

Harvest index $(\mathrm{HI})$ : Harvest index $(\mathrm{HI})$ of paddy crops was higher under sole agriculture as compared to the AF system (Table 4). During Ist cropping year, $\mathrm{HI}$ was recorded in between 37.97 to $39.59 \%$ under AF system, while it was 40.28 to $41.31 \%$ under sole agriculture. For IInd cropping year, it was 37.13 to $39.20 \%$ under AF system and 39.69 to $40.03 \%$ under sole agriculture system in study villages of Kosi watershed. Under agroforestry system Dhaniyakot showed highest $\mathrm{HI}(39.59 \%)$ while under sole agriculture Sauraal showed highest $\mathrm{HI}$ of $41.31 \%$ during Ist cropping year. During IInd cropping year, Dhaniyakot had highest $\mathrm{HI}$ of paddy crop under both land-use systems. Harvest Index of wheat crop was recorded slightly higher as compared to paddy. It was also higher under sole agriculture as compared to agroforestry systems (Table 4). During Ist cropping year, $\mathrm{HI}$ was in the range of 42.05 to $42.99 \%$ under AF system and 42.59 to $43.56 \%$ under sole agriculture system. For second year, $\mathrm{HI}$ was 38.03 to $41.42 \%$ under AF system and 40.59 to $42.92 \%$ under sole agriculture system. Harvest Index of wheat crop under AF system was recorded higher than the sole agriculture at Sauraal during Ist cropping year. However, it was higher under sole agriculture than the AF systems of Kantli, Dhaniyakot and Sauraal village during IInd year. Overall, Dhaniyakot showed highest $\mathrm{HI}$ under both the land use types.

The grain, straw, biological yield and harvest index of study crops were higher under sole agriculture as compared to AF system mainly due to competition for resources i.e. light, nutrients, water etc. between intercropped crops and trees under agroforestry. Under agroforestry system economic yield was $17.84-32.57 \%$ lower than the sole agriculture. Bijalwan (2012) record similar findings in Grahwal Himalaya where the annual productivity of food grains under AF systems was 34.56 to $38.29 \%$ lower than the sole agriculture. However, he also observed that this reduction in food production was supplemented by fruit production from the agroforestry trees. Grain yield of both paddy and wheat crops of present study are comparable with

Table 3. Grains, Straw and Biological yield of Wheat crop under AF system and sole agriculture system in Kosi watershed

\begin{tabular}{|c|c|c|c|c|}
\hline \multirow[t]{2}{*}{ Land use system/Study sites } & & \multicolumn{3}{|c|}{ Wheat yield $\left(\mathrm{kg} \mathrm{ha}^{-1}\right)$} \\
\hline & & Grain & Straw & Biological \\
\hline \multicolumn{5}{|l|}{ Agroforestry System } \\
\hline \multirow[t]{2}{*}{ Kantli (1750 m amsl) } & $I^{\text {st }}$ Year & $1294 \pm 42$ & $1783 \pm 92$ & $3077 \pm 142$ \\
\hline & $\mathrm{II}^{\text {nd }}$ Year & $1385 \pm 48.5$ & $1994 \pm 118.5$ & $3379 \pm 161.5$ \\
\hline \multirow[t]{2}{*}{ Dhaniyakot (1064 m amsl) } & $I^{\text {st }}$ Year & $1484 \pm 58.5$ & $1968 \pm 142$ & $3452 \pm 204.5$ \\
\hline & $\mathrm{II}^{\text {nd }}$ Year & $1608 \pm 66$ & $2274 \pm 162$ & $3882 \pm 223$ \\
\hline \multirow[t]{2}{*}{ Sauraal (839 m amsl) } & $I^{\text {st }}$ Year & $1021 \pm 23.5$ & $1361 \pm 112.5$ & $2382 \pm 91.5$ \\
\hline & $I^{\text {nd }}$ Year & $980 \pm 18$ & $1597 \pm 127$ & $2577 \pm 103$ \\
\hline \multicolumn{5}{|l|}{ Sole Agriculture } \\
\hline \multirow[t]{2}{*}{ Kantli (1750 m amsl) } & $\mathrm{I}^{\text {st }}$ Year & $1615 \pm 79.5$ & $2137 \pm 148$ & $3752 \pm 234$ \\
\hline & $I^{\text {nd }}$ Year & $1784 \pm 88.5$ & $2452 \pm 159.5$ & $4236 \pm 253.5$ \\
\hline \multirow[t]{2}{*}{ Dhaniyakot (1064 m amsl) } & $I^{\text {st }}$ Year & $1838 \pm 49$ & $2381 \pm 97$ & $4219 \pm 148$ \\
\hline & $\mathrm{II}^{\text {nd }}$ Year & $1945 \pm 57.5$ & $2587 \pm 109.5$ & $4532 \pm 165$ \\
\hline \multirow[t]{2}{*}{ Sauraal (839 m amsl) } & $I^{\text {st }}$ Year & $1254 \pm 19.5$ & $1698 \pm 94.5$ & $2952 \pm 112.5$ \\
\hline & $\mathrm{II}^{\text {nd }}$ Year & $1294 \pm 21$ & $1894 \pm 104.5$ & $3188 \pm 123$ \\
\hline
\end{tabular}


the average grain yields of these crops of Central Himalaya (Table 5). Yields of paddy and wheat crops are also comparable with the results of Toky et al (1989), Sundriyal et al (1994) and Singh (2010). There were little variations in the crop yields, which could be attributed to various crop compositions, tree density and quantity of fertilizer used (Sundriyal et al 1994). Among three study sites crop yield under both the agroforestry and sole agriculture systems was highest at Dhaniyakot because of better agriculture practices being followed in that village than the Kantli and Sauraal. The economic yield of any crop is dependent on the yield attributing characters, which are the ultimate outcome of the contribution of the growth characters. Further, these growth characters are function of photosynthesis, a universal physiological process of capturing and transforming the solar energy into more useful chemical energy (Kudtarkar 2005).

Increase in crop productivity of paddy and wheat may be attributed to change in climate, use of high yielding verities and fertilizers. Increase in $\mathrm{CO}_{2}$ concentration induced higher number of tillers and grain per plant that increase the rice

Table 4. Harvest index $(\mathrm{HI})$ of paddy and wheat crops under agroforestry system and sole agriculture

\begin{tabular}{|c|c|c|c|c|}
\hline \multirow[t]{2}{*}{ Parameters } & & \multicolumn{3}{|c|}{ Harvest index (\%) of crops } \\
\hline & & I Year & II Year & Mean \\
\hline \multicolumn{5}{|c|}{ Agroforestry system } \\
\hline \multirow[t]{2}{*}{ Kantli } & Paddy & $39.51 \pm 1.25$ & $37.19 \pm 1.08$ & $38.35 \pm 1.16$ \\
\hline & Wheat & $42.05 \pm 0.59$ & $40.99 \pm 0.46$ & $41.52 \pm 0.53$ \\
\hline \multirow[t]{2}{*}{ Dhaniyakot } & Paddy & $39.59 \pm 0.24$ & $39.20 \pm 0.17$ & $39.39 \pm 0.20$ \\
\hline & Wheat & $42.99 \pm 0.81$ & $41.42 \pm 0.74$ & $42.20 \pm 0.78$ \\
\hline \multirow[t]{2}{*}{ Sauraal } & Paddy & $37.97 \pm 0.45$ & $37.13 \pm 0.38$ & $37.55 \pm 0.42$ \\
\hline & Wheat & $42.86 \pm 2.67$ & $38.03 \pm 2.15$ & $40.44 \pm 2.42$ \\
\hline \multicolumn{5}{|c|}{ Sole Agriculture } \\
\hline \multirow[t]{2}{*}{ Kantli } & Paddy & $40.28 \pm 0.26$ & $39.8 \pm 0.19$ & $40.06 \pm 0.22$ \\
\hline & Wheat & $43.04 \pm 0.51$ & $42.12 \pm 0.42$ & $42.58 \pm 0.46$ \\
\hline \multirow[t]{2}{*}{ Dhaniyakot } & Paddy & $40.49 \pm 0.24$ & $40.03 \pm 0.21$ & $40.26 \pm 0.23$ \\
\hline & Wheat & $43.56 \pm 0.35$ & $42.92 \pm 0.29$ & $43.24 \pm 0.32$ \\
\hline \multirow[t]{2}{*}{ Sauraal } & Paddy & $41.31 \pm 0.86$ & $39.69 \pm 0.74$ & $40.5 \pm 0.81$ \\
\hline & Wheat & $42.48 \pm 0.98$ & $40.59 \pm 0.87$ & $41.53 \pm 0.94$ \\
\hline
\end{tabular}

Table 5. Grain yield of paddy and wheat (MT ha $\left.{ }^{-1}\right)$ in Central Himalaya

\begin{tabular}{lccc}
\hline Locations & Paddy & Wheat & Reference \\
\hline Almora district & 1.00 & 1.30 & Sati and Deng Wei (2018) \\
Almora district & 1.02 & 1.08 & Mittal et al (2008) \\
Central Himalaya & 1.41 & 1.52 & Mukerjee et al (2018) \\
Uttarakhand & $1.98-2.14$ & $1.88-2.43$ & Tuteja (2015) \\
Uttarakhand & 1.74 & 1.85 & Mittal et al (2008) \\
Garhwal Himalaya & NA & $1.03-1.06$ & Bijalwan (2012) \\
$\quad$ Sole agriculture & NA & & Bijalwan (2012) \\
$\quad$ Agroforestry & & $0.59-0.66$ & Present study \\
Agroforestry & 1.22 & & Present study \\
$\quad$ Kantli & 1.43 & 1.34 & Present study \\
$\quad$ Dhaniyakot & 0.96 & 1.55 & Present study \\
$\quad$ Sauraal & & 1.00 & Present study \\
Kantli & 1.52 & 2.29 & Present study \\
Dhaniyakot & 1.69 & 2.48 & 1.80 \\
Sauraal & 1.26 & &
\end{tabular}


grain yields. Additional carbohydrate in paddy plants has helped in balancing the profile of photosynthetic proteins to sustain greater photosynthetic activity (Uprety et al 2004). In their study, Attri and Rathore (2003) predicted enhancement of $29-37 \%$ in the wheat yield under climate change conditions of northwest India. Kanwal et al. (2019) also projected increase in the yield of rice (30-40\%) and wheat (28-31\%) with changing climate scenario in Kumaun Himalaya. However, Birthal et al (2014) projected decrease in average yield of rice and wheat, respectively up to 15 and $22 \%$ by 2100 with increasing temperature and rainfall for all the districts of India. The contradiction may be corroborated to the fact that a temperature rise up to $3^{\circ} \mathrm{C}$ at the Himalayan region may result in a better rice producing condition unlike the Gangetic and peninsular India where it may lead to heat stress.

\section{Soil Properties}

Soil pH: Soil pH of the nearby forests, particularly $0-15 \mathrm{~cm}$ soil layers of all the three villages were slightly acidic in nature and their $\mathrm{pH}$ ranged between 6.20 to 6.44 (Table 6). It was followed by AF system. Further, soil $\mathrm{pH}$ changed from acidic to alkaline with increase of soil depths. Overall, there was not much variation in soil $\mathrm{pH}$ under control with increase in soil depths. For sustained cultivation of food crops such as paddy, wheat, vegetables pulses during two cropping

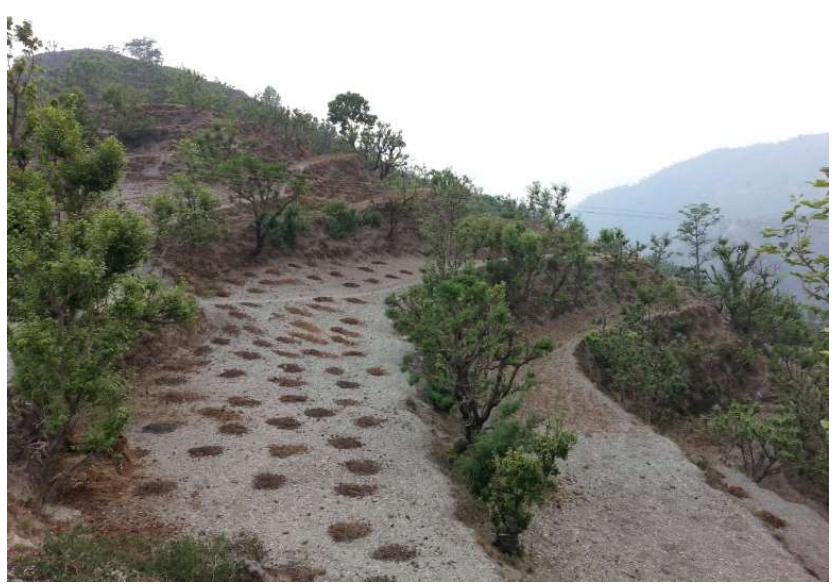

Fig. 2. Amendments of organic manure in crop fields in Kosi watershed seasons i.e. Kharif and Rabi seasons in a year, soil nutrients are managed by mixing decomposed organic manure in farms (Fig. 2). Organic manure is prepared with cattle dung and dried pine needles and leftover fodder leaves mixed with cattle urine as beddings (dried forest leaves, leftover fodder and unpalatable straw etc.) on floor of cattle sheds under cattle during night. When bedding is mixed with dung and urine it is kept in pits for decomposing; after complete decomposition organic manure is ready for mixing in the crop fields. Chemical fertilizer such as urea is also used during paddy and wheat cropping. Soil organic matter and regular use of organic manure may increases soil pH in acidic soils whereas use of chemical fertilizers decreases soil $\mathrm{pH}$ (Whalen et al 2000). Soils of Kantli and Sauraal were acidic in upper layers of $0-15 \mathrm{~cm}$ depth and remaining two layers i.e. 15 to $30 \mathrm{~cm}$ and 30 to $15 \mathrm{~cm}$ were either neutral or slightly basic. Soil pH was much lower under agroforestry and forests as compared to control. Further, $\mathrm{pH}$ was much lower under forests compared to agroforestry. Soil $\mathrm{pH}$ was lower in the higher soil depths. The lower $\mathrm{pH}$ in $0-15 \mathrm{~cm}$ soil depth under tree species could be attributed to accumulation of organic matter in the soil by falling of leaves, small twigs and decomposition of below ground parts i.e. fine roots that subsequently produce organic acids (Gupta and Sharma 2008). Similar results were reported in agri-silviculture system by Prasadini and Sreemannarayana (2007) and Kumar et al (2008). Newaj et al (2007) also observed very nominal changes in soil $\mathrm{pH}$ under white siris (Albizia procera) based agri-silviculture system after 4 years of experimentation as compared to initial value due to very high free calcium carbonate content in the soils.

Water holding capacity (WHC): Water holding capacity (WHC) of soils were better under all agroforestry sites as compared to controls. However, it was best under forests as compare to agroforestry and control sites (Table 7). Further, WHC of soils under agroforestry and forests were better at Kantli (higher altitude sites) than the soils of middle altitude (Dhaniyakot) and lower altitude (Sauraal). It was also found that WHC was higher under upper soil layers $(0-15 \mathrm{~cm})$ than middle layers $(15-30 \mathrm{~cm})$ and lower layers $(30-45 \mathrm{~cm})$ at all the sites and all landuse types.

In present study, water holding capacity (WHC) was

Table 6. Soil pH from different soil depths of different land use types

\begin{tabular}{|c|c|c|c|c|c|c|c|c|c|c|c|c|}
\hline \multirow[t]{2}{*}{ Parameters } & \multicolumn{4}{|c|}{$\begin{array}{l}\text { Kantli (1750 m amsl) } \\
\text { Soil depth }(\mathrm{cm})\end{array}$} & \multicolumn{4}{|c|}{$\begin{array}{c}\text { Dhaniyakot }(1064 \mathrm{~m} \text { amsl) } \\
\text { Soil depth }(\mathrm{cm})\end{array}$} & \multicolumn{4}{|c|}{$\begin{array}{l}\text { Sauraal }(839 \mathrm{~m} \text { amsl) } \\
\text { Soil depth }(\mathrm{cm})\end{array}$} \\
\hline & $(0-15)$ & $(15-30)$ & $(30-45)$ & Mean & $(0-15)$ & $(15-30)$ & $(30-45)$ & Mean & $(0-15)$ & $(15-30)$ & $(30-45)$ & Mean \\
\hline Agroforestry & $6.51 \pm 0.49$ & $6.71 \pm 0.60$ & $7.52 \pm 0.06$ & 6.91 & $6.31 \pm 0.10$ & $7.52 \pm 0.03$ & $7.57 \pm 0.03$ & 7.13 & $6.45 \pm 0.27$ & $6.51 \pm 0.35$ & $6.16 \pm 0.84$ & 6.37 \\
\hline Forest & $6.44 \pm 0.03$ & $7.20 \pm 0.04$ & $7.62 \pm 0.09$ & 7.08 & $6.20 \pm 0.06$ & $7.24 \pm 0.02$ & $7.28 \pm 0.03$ & 6.90 & $6.36 \pm 0.22$ & $6.49 \pm 0.28$ & $7.14 \pm 0.03$ & 6.66 \\
\hline Control & $6.79 \pm 0.28$ & $7.01 \pm 0.38$ & $7.60 \pm 0.19$ & 7.13 & $6.68 \pm 0.03$ & $6.67 \pm 0.02$ & $6.70 \pm 0.02$ & 6.68 & $6.56 \pm 0.49$ & $6.89 \pm 0.17$ & $6.93 \pm 0.01$ & 6.79 \\
\hline
\end{tabular}


superior under forests followed by agroforestry system and lowest at control sites. It was lowest in lower soil depths as compared to upper two soil depths. Similar results were obtained by Subba and Dhara (2017) under fruit based agroforestry systems. In his study, Felker (1978), indicated WHC of soil increases under Acacia albida in comparison with sites devoid of such trees. Udawatta et al. (2011) also reported that perennial vegetation increases infiltration rate and water holding capacity of the soil. Singh and Singh (2011) and Chauhan et al. (2018) also reported higher WHC of soil in woodland as compared to control. They concluded two to three folds higher soil moisture in multi-storey plots as compared to control. The effect of increased two to three folds higher is believed to be a consequence of higher topsoil organic matter content under trees in forest and agroforestry systems than the sole agriculture or monoculture system.

Soil moisture content: Soil moisture contents of forested sites were better than the soil moisture of agroforestry and control in all the sites. Soil moisture contents of agroforestry sites were higher than the control (Table 7$)$. In middle soil depth $(15-30 \mathrm{~cm})$ and lower soil depth $(30-45 \mathrm{~cm})$ soil moisture content was higher than the upper soil $(0-15 \mathrm{~cm})$, particularly under forests and control sites. Among AF systems, Kantli and Sauraal villages soil has higher moisture as compared to agroforestry system of Dhaniyakot.

Higher soil moisture content of forests and agroforestry systems could be attributed to more litter production and subsequent litter decomposition under trees favouring higher soil moisture retention capacity (Vanlalhluna, 2007). The higher value of $\mathrm{WHC}$ and soil moisture at Kantli might also be due to oak forests, as higher amount of litter in oak forests influences the texture of soil that results in higher water retention capacity. But in case of Dhaniyakot having higher concentration of $\mathrm{OC}$, yet the water holding capacity is very low. This might be due to the sandy texture of soil; sandy soil has small surface area and less pore volume subsequently retains less moisture.

Organic carbon (OC): Among agroforestry systems maximum organic carbon (OC) was observed under agroforestry system of Dhaniyakot followed by Sauraal and minimum under agroforestry system of Kantli village (Table 8). OC was recorded maximum in the upper soil depths (0-15 $\mathrm{cm}$ ) across all the study sites and showed trend of decline in lower soil layers of $15-30 \mathrm{~cm}$ and $30-45 \mathrm{~cm}$. OC was relatively higher under forest soils than the agroforestry soils. Both the agroforestry and forest soils had higher concentration of OC than control in general. High organic matter content (up to $30 \%$ ) in organic manure is believed to increase the content of organic corban, nitrogen, phosphorus, potassium, and main cations in the soil (Han et al 2016, Sheikh and Dwivedi 2017). The organic matter of manure allows plants to use the nutrients for a long time, due to its slow decomposition, and reduces the loss of what is not utilized by the plants (Bhandari et al 2002). Potassium, and

Table 7. Water holding capacity and soil moisture (\%) from different soil depths of different land use types

\begin{tabular}{|c|c|c|c|c|c|c|c|c|c|c|c|c|}
\hline \multirow[t]{2}{*}{ Parameters } & \multicolumn{4}{|c|}{$\begin{array}{l}\text { Kantli (1750 m amsl) } \\
\text { Soil depth }(\mathrm{cm})\end{array}$} & \multicolumn{4}{|c|}{$\begin{array}{l}\text { Dhaniyakot (1064 m amsl) } \\
\text { Soil depth }(\mathrm{cm})\end{array}$} & \multicolumn{4}{|c|}{$\begin{array}{l}\text { Sauraal }(839 \mathrm{~m} \text { amsl) } \\
\text { Soil depth }(\mathrm{cm})\end{array}$} \\
\hline & $(0-15)$ & $(15-30)$ & $(30-45)$ & Mean & $(0-15)$ & $(15-30)$ & $(30-45)$ & Mean & $(0-15)$ & $(15-30)$ & $(30-45)$ & Mean \\
\hline \multicolumn{13}{|c|}{ Water holding capacity (\%) } \\
\hline Agroforestry & 53.06 & 52.39 & 52.32 & 52.59 & 52.26 & 50.7 & 50.45 & 51.13 & 49.78 & 48.75 & 48.18 & 48.90 \\
\hline Forest & 55.39 & 54.67 & 53.13 & 54.39 & 54.43 & 52.18 & 52.0 & 52.87 & 51.21 & 52.21 & 51.02 & 51.48 \\
\hline Control & 53.22 & 49.53 & 48.65 & 50.46 & 48.26 & 46.85 & 47.7 & 47.60 & 44.57 & 43.57 & 44.12 & 44.08 \\
\hline \multicolumn{13}{|c|}{ Soil moisture (\%) } \\
\hline Agroforestry & 12.35 & 17.4 & 16.34 & 15.36 & 9.52 & 7.25 & 8.34 & 8.37 & 13.35 & 15.20 & 12.21 & 13.58 \\
\hline Forest & 13.32 & 14.52 & 16.23 & 14.69 & 12.34 & 12.56 & 14.36 & 13.08 & 13.96 & 17.96 & 16.86 & 16.26 \\
\hline Control & 5.53 & 6.49 & 8.52 & 6.84 & 8.75 & 7.48 & 7.62 & 7.95 & 8.31 & 11.55 & 11.85 & 10.57 \\
\hline
\end{tabular}

Table 8. Organic carbon (\%) from different soil depths of different land use types

\begin{tabular}{|c|c|c|c|c|c|c|c|c|c|c|c|c|}
\hline \multirow[t]{2}{*}{ Parameters } & \multicolumn{4}{|c|}{$\begin{array}{l}\text { Kantli (1750 m amsl) } \\
\text { Soil depth }(\mathrm{cm})\end{array}$} & \multicolumn{4}{|c|}{$\begin{array}{c}\text { Dhaniyakot }(1064 \mathrm{~m} \text { amsl) } \\
\text { Soil depth }(\mathrm{cm})\end{array}$} & \multicolumn{4}{|c|}{$\begin{array}{l}\text { Sauraal }(839 \mathrm{~m} \text { amsl) } \\
\text { Soil depth }(\mathrm{cm})\end{array}$} \\
\hline & $(0-15)$ & $(15-30)$ & $(30-45)$ & Mean & $(0-15)$ & $(15-30)$ & $(30-45)$ & Mean & $(0-15)$ & $(15-30)$ & $(30-45)$ & Mean \\
\hline Agroforestry & $2.04 \pm 0.24$ & $1.41 \pm 0.19$ & $1.38 \pm 0.16$ & 1.61 & $2.45 \pm 0.26$ & $1.50 \pm 0.17$ & $1.24 \pm 0.19$ & 1.73 & $2.33 \pm 0.21$ & $1.33 \pm 0.19$ & $1.15 \pm 0.22$ & 1.60 \\
\hline Forest & $2.32 \pm 0.26$ & $1.85 \pm 0.15$ & $1.64 \pm 0.11$ & 1.93 & $2.51 \pm 0.23$ & $1.96 \pm 0.17$ & $1.44 \pm 0.13$ & 1.97 & $2.45 \pm 0.19$ & $1.68 \pm 0.12$ & $1.50 \pm 0.16$ & 1.87 \\
\hline Control & $1.42 \pm 0.15$ & $1.22 \pm 0.19$ & $1.02 \pm 0.14$ & 1.22 & $2.20 \pm 0.20$ & $1.15 \pm 0.24$ & $1.05 \pm 0.11$ & 1.46 & $1.32 \pm 0.13$ & $1.22 \pm 0.14$ & $1.08 \pm 0.11$ & 1.20 \\
\hline
\end{tabular}


nitrogen increased by organic manure treatment due to their high content in organic manure.

In the present study, soil organic corban (SOC) varied between 1.32 to $2.20 \%$ in upper layer of $0-15 \mathrm{~cm}$ under control, 2.32 to $2.51 \%$ under forest and 2.04 to $2.45 \%$ under agroforestry system. SOC in agroforestry soils, particularly uper layer, i.e. $0-15 \mathrm{~cm}$ depth was higher due to manuring the crop fields with organic manure. The range of $\mathrm{OC}$ in soils 2.32 to $2.51 \%$ in chir pine forests were reported earlier by Goswami (2014). While in the similar agroforestry systems, Bhardwaj et al (2013) observed SOC contents ranging from 0.89 to $1.22 \%$ only. SOC was miximum under forest followed by agroforestry system. The soil enrichment in SOC content under tree based systems could be due to several factors such as addition of litter, decomposition of fine roots biomass and root exudates and its reduced oxidation of organic matter under tree shades (Gill and Burman 2002). Studies indicate addition of leaf litter favours the higher nutrient status of the soil (Uthappa et al 2015). Lower organic carbon under agroforestry system of Kantli village may be due to the agricultural practices like removal of crop residue from the field after harvesting of previous sown crop whereas at Dhaniyakot farmers do not remove the crop residues from the crop fields and plough the field along with residues. The highest SOC (\%) was recorded at the surface soil layer (0-15 $\mathrm{cm}$ ) while the lowest SOC (\%) was observed for $30-45 \mathrm{~cm}$ soil depth. This may be attributed to the major contribution made by litter fall at surface layer. Similar variation in SOC with soil depth has also been reported by Chauhan et al (2010), Ghimire (2010) and Uthappa et al (2015). Generally, the plants have lignified cells in its parts like litter, bark, small branches, roots etc. that may leads to biochemical stabilization of organic carbon in the soil and leads to improve SOC (\%) under agroforestry as concluded by Six et al (2002). Hence, one of the reasons which reveal the lower concentration of SOC under control (without vegetation) is lack of lignified cells.

\section{CONCLUSION}

Local people evolved traditional agroforestry system on terraced hilly soils to meet their food, fodder and fuel wood requirement from this system with trial and error method over a time period. Cereal cultivation along with agroforestry on terraced hill slopes of central Himalayan regions is an example of such system. This system does not meet only some of their primary necessity of the local people but also provide soil benefits. Although, crop yields and harvest index were higher under sole agriculture as compared to the agroforestry but overall profit in agroforestry is higher due to addition of tree biomass. Moreover, it provides better livelihood security, ecosystem services and biodiversity conservation than a mono-cropping system. In pure agriculture some chemical fertilizers are also used which are ecologically undesirable whereas under agroforestry for sustained cultivation of food crops during two cropping seasons in a year, soil nutrients are managed by mixing decomposed organic manure in farms. Further, better soil properties were observed under forest and agroforestry sites as compared to without vegetation site mainly due to addition of organic matter in the soil. This study is limited to only two important cereal crops of the region for a short period of two cropping years. Similar observations on other hill crops, pulses and vegetables on a longer period basis needs be carried out to understand impact of various interactions between agroforestry components. In the present scenario to feed growing population with limited resources, land area and increase in deforestation rate traditional agroforestry system would be viable option in Kumaun Himalaya which can be strengthen by suitable policies for hilly states, better management practices, proper site selection, plantation of multipurpose tree species, appropriate tree-crop combination and arrangement.

\section{REFERENCES}

Attri S and Rathore L 2003. Simulation of impact of projected climate change on wheat in India. International Journal of Climatology 23: 693-705.

Bhandari AL, Ladha JK, Pathak H, Padre AT, Dawe D and Gupta RK 2002. Yield and soil and nutrient changes in a long term ricecowpea cropping system in semi arid tropics. Plant Soil 318: 2735.

Bhardwaj DR, Sanneh A, Rajput BS and Kumar S 2013. Status of soil organic carbon stocks under different land use systems in wet temperate north western Himalaya. Journal of Tree Sciences 32: 15-22.

Bhatt BP, Parmar B, Bordoloi LJ and Bhattacharyya R 2016. Impacts of agroforestry systems on soil and nutrient conservation in the Eastern Himalayas, India. International Journal of BioResource \& Stress Management 7: 575-581.

Birthal P, Khan M, Negi D and Agarwal S 2014. Impact of climate change on yields of major food crops in India: Implications for food security. Agricultural Economics Research Review 27(2): 145-155.

Bijalwan A 2012. Structure, composition and diversity of horticulture trees and agricultural crops productivity under traditional agrihorticulture system in mid hill situation of Garhwal Himalaya, India. American Journal of Plant Sciences 3: 480-488.

Broadhead JS, Black CR and Ong CK 2003. Tree leafing phenology and crop productivity in semi-arid agroforestry system in Kenya. Agroforestry Systems 58(2): 137-148.

Cassel DK and Nielsen DR 1986. Field capacity and available water capacity. In: ALRH Miller and D R Keeney (Eds.), Methods of soil analysis part 2: Chemical and microbiological properties Second edition. Agronomy Society of America, Madison, WI.

Chauhan SK, Sharma SC, Beri V, Ritu, Yadav S and Gupta N 2010. Yield and carbon sequestration potential of wheat (Triticum aestivum)-poplar (Populus deltoides) based agrisilvicultural system. Indian Journal of Agricultural Sciences 80(2): 129-135.

Chauhan SK, Sharma R, Singh B and Sharma SC 2015. Biomass 
production, carbon sequestration and economics of on-farm poplar plantations in Punjab, India. Journal of Applied and Natural Science 7(1): 452-458.

Chauhan SK, Singh S, Sharma S, Vashist BB, Sharma R and Saralch HS 2018. Soil health (physical, chemical and biological) status under short rotation tree plantations on riverain soils. Journal of Pharmacognosy and Phytochemistry 7(5): 1599-1605.

Chauhan SK, Singh S, Sharma S, Sharma R and Saralch HS 2019. Tree biomass and carbon sequestration in four short rotation tree plantations. Range Management and Agroforestry 40(1): 77-82.

Dufour L, Metay A, Talbot G, Dupraz C 2013. Assessing light competition for cereal production in temperate agroforestry systems using experimentation and crop modelling. Journal of Agronomy and Crop Science 199(3): 217-227.

Fagerholm N, Torralba M, Burgess PJ and Plieninger T 2016. A systematic map of ecosystem services assessments around European agroforestry. Ecological Indicators 62:47-65.

Felker P 1978. State of the art: Acacia albida as a complementary permanent intercrop with annual crops. University of California, Riverside.

Ghimire TB 2010. Effect of fertility levels on mustard (Brassica juncea L.) productivity under varying poplar tree densities. Ph.D. Thesis. G.B. Pant University of Agriculture \& Technology, Pantnagar-263 145, Uttarakhand. 309p.

Gill AS and Burman D 2002. Production management of field crops in agroforestry systems. In: Recent advances in Agronomy. Singh G, Kolar JS and Sekhon HS (Eds.) New Delhi, Indian Society of Agronomy. pp. 523-542.

Goswami S, Verma KS and Kaushal R 2014. Biomass and carbon sequestration in different agroforestry systems of a Western Himalayan watershed. Biological Agriculture \& Horticulture: An International Journal for Sustainable Production Systems 30(2): 88-96.

Guevara-Escobar A, Kemp PD, Mackay AD and Hodgson J 2002. Soil properties of a widely spaced, planted poplar (Populus deltoides)-pasture system in a hill environment. Australian Journal of Soil Research 40: 873-886.

Gupta MK and Sharma SD 2008. Effect of tree plantation on soil properties, profile morphology and productivity index in Uttarakhand. Annals of Forestry 16(2): 209-224.

Han SH, An JY, Hwang J, Kim SB and Park BB 2016. The effect of organic manure and chemical fertilizer on the growth and nutrient concentrations of yellow poplar (Liriodendron tulipifera Lin.) in a nursery system. Forest science and Technology 12(3): 137-143.

Harvey CA, Gonzales JG and Somarriba E 2006. Dung beetle and terrestrial mammal diversity in forest, indigenous agroforestry systems and plantain monocultures in Talamanca, Costa Rica. Biodiversity and Conservation 15: 555-585.

liyama $M$, Neufeldt $H$, Dobie $P$, Njenga $M$, Ngegwa $G$ and Jamnadass R 2014. The potential of agroforestry in the provision of sustainable woodfuel in sub-Saharan Africa. Current Opinion in Environmental Sustainability 6:138-147.

Jackson ML 1958. Soil chemical analysis. Prentice Hal Inc., USA, $498 p$.

Jose S 2009. Agroforestry for ecosystem services and environmental benefits: An overview. Agroforest Systems 76: 1-10.

Kanwal MS, Mukherjee S, Joshi R and Rai S 2019. Impact assessment of changing environmental and socio-economical factors on crop yields of Central Himalaya with emphasis to climate change. Environment and Ecology 37(1B): 324-332.

Köppen W 1900. Versuch einer Klassifikation der Klimate, Vorzugsweise nach ihren Beziehungen zur Pflanzenwelt [Attempted climate classification in relation to plant distributions]. Geographische Zeitschrift 6: 593-611.

Kudtarkar US 2005. Effect of polythene mulch, levels of organic manure and fertilizer on the performance of rabi ground nut. M.Sc. Thesis, Agriculture, Konkan Krishi Vidyapeeth, Dapoli, India.

Kumar K, Laik R, Das DK and Charturvedi OP 2008. Soil microbial biomass and respiration in afforested calciorthent. Indian Journal of Agroforestry 10(2): 75-83.

Lehmann LM, Smith J, Westaway S, Pisanelli A, Russo G, Borek R, Sandor M, Gliga A, Smith L and Ghaley BB 2020. Productivity and economic evaluation of agroforestry systems for sustainable production of food and non-food products, sustainability 12: 5429; doi:10.3390/su12135429.

Maikhuri RK and Semwal RL 1997. Agroforestry for rehabilitation of degraded community lands: A case study in the Garhwal Himalaya, India. International Tree Crops Journal 9: 89-99.

Mittal S, Tripathi G and Sethi D 2008. Development Strategy for the Hill Districts of Uttarakhand. Working Paper No. 217, July 2008. ICRIER.

Montagnini F and Nair PKR 2004. Carbon sequestration: An underexploited environmental benefit of agroforestry systems. Agroforestry Systems 61(1-3): 281

Mukerjee P, Sogani R, Gurung N, Rastogi A and Swiderska K 2018. Smallholder farming systems in the Indian Himalayas: Key trends and innovations for resilience. IIED Country Report. IIED, London.

Nair PK, Kumar BM and Nair VD 2009. Agroforestry as a strategy for carbon sequestration. Journal of Plant Nutrition and Soil Science 172: 10-23.

Newaj R, Dar SA, Bhargava MK, Yadav RS and Ajit 2007. Effect of management practices on growth of white siris (Albezia procera), grain yield of intercrops, weed population and soil fertility changes in agrisilviculture system in semi-arid India. Indian Journal of Agricultural Sciences 77(7): 403-407.

Pandey U and Singh JS 1984. Energetics of hill agro-ecosystems: A case study from Central Himalaya. Agriculture Systems 13: 8395.

Prasadini P and Sreemannarayana B 2007. Impact of agroforestry systems on nutritional status and biological activity on rainfed red sandy loam soils. Indian Forester 133(11): 1519-1525.

Puri S and Bangarwa KS 1992. Effect of trees on the yield of irrigated wheat crop in semi-arid regions. Agroforestry Systems 20: 229241.

Rao JV 2002. Wasteland development. Summer school on land use diversification in rainfed agro-economic (April 15-5 May 2002). Compendium of lectures. pp. 467-476.

Saroj PL and Arora YK 1994. Horticulture based agroforestry Systems of Doon valley. Indian Journal of Soil Conservation 22(3): 60-65.

Sati VP and Deng W 2018. Crop productivity and suitability analysis for land-use planning in Himalayan ecosystem of Uttarakhand, India. Current Science 115(4): 767-772.

Schroth G and Sinclair F 2003. Trees crops and soil fertility: Concepts and research methods. CABI, Wallingford, UK, p 464.

Semwal RL, Maikhuri RK, Rao KS, Singh K and Saxena KG 2002. Crop productivity under differently lopped canopies of multipurpose trees in Central Himalaya, India. Agroforestry System 56(1): 57-63.

Sheikh MA and Dwivedi P 2017. Physico-chemical parameters of organic manure, soil and impact of organic manure and NPK fertilizer on seed germination of soyabean and wheat. International Journal of Engineering Technologies and Management Research 4(12:SE): 118-130. DOI: 10.5281/zenodo.1163891.

Singh, A, Sharma R, Chauhan, SK and Arora D2016. Microclimate and turmeric yield under different tree species. Journal of Agrometeorology 18(2): 320-323.

Singh JS and Singh KD 2011. Silviculture of dry deciduous forests, India. In: Silviculture in the Tropics. Springer, Berlin Heidelberg, pp. 273-283. 
Singh K 2010. Biomass consumption and assessment of cropping and yield patterns of various components under different traditional agroforestry systems across an altitudinal gradients in Kumaun region of central Himalaya. Ph.D. Thesis. Bundelkhand University.

Six J, Conant RT, Paul EA and Paustain K 2002. Stabilization mechanism of soil organic matter: Implication for carbon saturation of soil. Plant and Soil 241: 155-176.

Srivastava A2006. Sustainability of field agriculture agro-ecosystems and watersheds. In: Sustainable production from agricultural watersheds in North-West Himalaya. Vivekanada Parvatiya Krishi Anusandhan Sansthan, Almora, Uttarakhnad, India.

Subba B and Dhara PK 2017. Influence of fruit based agroforestry systems on soil properties for sustainable soil health in hill zone of West Bengal, India. International Journal of Plant \& Soil Science 16(5): 1-12.

Sundriyal RC, Rai SC, Sharma E and Rai YK 1994. Hill agroforestry systems in south Sikkim, India. Agroforestry Systems 26(3): 215-235.

Tadesse S, Gebretsadik W, Muthuri C, Derero A and Hadgu K 2021. Crop productivity and tree growth in intercropped agroforestry system in semi-arid and sub-humid regions of Ethiopia. Agroforestry Systems 95(3): 487-498.

Tanga AA, Erenso TF and Lemma B 2014. Effects of three tree species on microclimate and soil amelioration in the central rift valley of Ethiopia. Journal of Soil Science and Environmental Management 5(5): 62-71.

Toky OP, Kumar P and Khosla PK 1989. Structure and function of traditional Agroforestry system in the western Himalaya. I. Biomass and Productivity. Agroforestry Systems 9: 47-70

Tuteja U 2015. Agriculture Profile of Uttrakhand. Agricultural Economics Research Centre University of Delhi.

Udawatta RP, Anderson SH, Motavalli PP and Garrett HE 2011.

Received 21 September, 2021; Accepted 10 January, 2022
Calibration of a water content reflectometer and soil water dynamics for an agroforestry practice. Agroforestry Systems 82(1): 61-75.

Uprety DC, Mitra AP, Garg SC, Kimball B and Lawlor D 2004. Rising atmospheric carbon dioxide and crop responses. In: Jain H.K., Kharkwal M.C. (eds) Plant Breeding. Springer, Dordrecht. pp. 749-758.

Uthappa AR, Bana OPS, Kumar M and Kanwal M 2015. Soil physicobio-chemical properties as influenced by varying tree densities in poplar based agroforestry system. Indian Journal of Agroforestry 17(1): 81-90.

Vanlalhluna PC 2007. Studies on tree-crop compatibility and growth performance of field crops and soil moisture conservation as affected by different mulches under hilly terrain of Mizoram. Ph.D. Thesis. Mizoram University, Aizawal.

Verma KS, Zegeye MW and Kaushal R 2002. Growth and yield performance of wheat in agri-horti-silvicultural system of agroforestry in mid-hills of Himachal Himalayas. Indian Journal of Agroforestry 4(1): 1-7.

Verma P, Bijalwan A, Dobriyal MJR, Swamy SL and Thakur TK 2017. A paradigm shift in agroforestry practices in Uttar Pradesh. Current Science 112(3): 509-516.

Waldron A, Garrity D, Malhi Y, Girardin C, Miller DC and Seddon N 2017. Agroforestry can enhance food security while meeting other sustainable development goals. Tropical Conservation Science 10:1-6.

Walkley AE and Black JA 1934. An examination of the Degtijareff method for determining soil organic matter and proposed modification of the chromic acid titration method. Soil Science 37(1): 29-38.

Whalen JK, Chang C and Carefoot JP 2000. Cattle manure amendments can increase the $\mathrm{pH}$ of acid soils. Soil Science Society of America Journal 64: 962-966. 